\title{
Stabilization Characteristics of Different Loose Sandy Soils using Microbial-Induced Calcite Precipitation
}

\author{
Naglaa MOHAMED ${ }^{1}$, Nehad HAFEZ ${ }^{2}$, \\ Medhat EL-MAHLLAWY ${ }^{3, *}$ and Abbas SHARAKY ${ }^{1}$ \\ ${ }^{I}$ Faculty of African Postgraduate Studies, Cairo University, Egypt \\ ${ }^{2}$ National Water Research Center, Egypt \\ ${ }^{3}$ Housing and Building National Research Center (HBRC), Egypt
}

("Corresponding author's e-mail: medhatt225@yahoo.com)

Received: 9 November 2019, Revised: 16 May 2020, Accepted: 10 June 2020

\begin{abstract}
Loose sands (siliceous, silty, and calcareous classes) are extensively found near arid areas in Egypt. Furthermore, many geotechnical structures, like water channels and roads, may be constructed on weak or loose sand soils. The geotechnical behavior of loose sands is usually connected with different interdependent problems, such as high permeability, low shear strength, low bearing capacity, high seepage, and low stability. This work characterized the effect of stabilization of the siliceous, silty, and calcareous sandy soils via biocementation process using Sporosarcina pasteurii bacteria as a potential eco, commercial, and engineering solution. This was carried out using bacteria, fixation, and cementation solutions (BFC) at different times number additions. The results indicated that the addition times of solution have a remarkable effect on the physical and mechanical properties of sandy soils. The results also proved that the precipitation of calcite by the bacterial activity led to cohesion of soil grains, and this increased the resistance of soils to deterioration. In addition, the high content of the precipitated calcium carbonate enhanced the shear strength and the unconfined compressive strength and decreased the soil permeability. S. pasteurii bacteria can be used successfully and commercially in the biocementation process for siliceous sand, silty sand, and calcareous sandy soils in Egypt using the recommended conditions and mixes.
\end{abstract}

Keywords: Sporosarcina pasteurii, Biocementation, Calcite, Properties, Durability.

\section{Introduction}

Loose sandy soils are most prone to water erosion, particularly in areas of high rainfall and ground slopes. Water channel embankments made of siliceous, calcareous, and silty sand loose soils may suffer from slope stability problems. These problems are considered some of the common canal embankment problems in Egypt. Soil stabilization is one of the economic engineering solutions to overcome soil problems [1].

Soil stabilization can be carried out by several methods. All of these methods belong to 2 broad categories: Mechanical stabilization, which depends on the physical nature of soil particles, and chemical stabilization, which depends mainly on the chemical reactions between the used stabilizer and soil grains [2]. Ordinary Portland cement, lime [3], fly ash, bitumen, industrial wastes and fibers [4], or a combination of these materials are the most common used chemical stabilization materials [5].

To improve the engineering properties of soil, various techniques have been applied, such as mechanical stabilization [6], soil replacement [7], and structural reinforcement by structural fill, admixtures, grouting, and others [8]. 
http://wjst.wu.ac.th

Traditional stabilization of a soil mass may be required when the surficial techniques are insufficient and in situ strengthening techniques like chemical grouting are needed. However, chemical grouting technique is often expensive and requires digging wells for grouting injection at large volumes. This method significantly reduces the permeability and strength of the soil, but hinders groundwater flow and limits long distance injection, making the treatment unfeasible. So, biological technique (bio grouting) can be considered a good solution [9].

Currently, new ground reinforcement techniques are being developed based on biocementation. This method is a bio-geochemical process that induces carbonate precipitation within the soil matrix. This method is mainly composed of 3 constituents, namely, alkalophilic microbe, substrate solution (urea), and calcium ion solution [10-14], where bacteria feed on the nutrients found in media to grow the cells, urea is used as a substrate hydrolyzed material, and calcium acts as the energy source to form the calcite [1517]. The cohesion of sand particles by biocementation is very useful in geotechnical engineering to minimize the effect of erosion and increase slope stability [18].

Sporosarcina pasteurii ( $S$. pasteurii) is known to be non-toxigenic and non-pathogenic to the human species. It is a gram-positive bacterium able to survive in highly alkaline environments $(\mathrm{pH} \sim 10)$ and is one of the bacterial species that can become a causative agent of a phenomenon called microbiologically induced calcite precipitation. It is the most used bacterial species for the biocementation purpose for sandy soil $[19,20]$. S. pasteurii plays a significant role in increasing the compressive strength of biocemented samples due to the precipitation of calcium carbonate by the action of bacterial activity [21].

Not so long ago, the biocementation technique attracted much attention, because it is a type of green material and represents a sustainable and long-term remediation method used for the enhancement of building structures; additionally, it is cost effective [22-29].

The advantages of the biocementation technique are as follows: 1 . the avoidance of using polymers, organic solvents, and resins as cementing agents; 2 . both the cementing agents and the solvents applied being non-toxic/non-harmful to the environment; 3. the avoidance of using Portland cement, a material for which the production greatly contributes to the emission of $\mathrm{CO}_{2} ; 4$. the technique employing aqueous mixtures of the reacting components (ureolytic bacteria/free urease, urea, and Ca salt); 5 . the cementing agent not being injected into the material, but formed in situ on the soil, following the same reaction as in nature; 6 . the process being carried out in mild conditions. These points classify the technique as an environmentally-friendly and sustainability-promoting approach to geotechnical and construction engineering applications [30].

In situ calcite bioprecipitation has been studied for various possible applications, such as the preservation of the limestone artifacts [31], the plugging up of the pores of oil recovery reservoir rocks and removing the contaminants in groundwater systems [32], the reduction the swelling potential of clayey soil, and the minimization of the liquefaction potential of soil [9]. This research aims to study the effect of the biocementation (stabilization) process on the properties of different types of loose sandy soils as a possible eco, commercial, and engineering solution to improve these common soils in Egypt.

\section{Materials and methods}

\section{Materials}

Soils

In this study, representative samples from 3 different sandy soils in Egypt were used for the experimental work; siliceous sandy soil, silty sand soil, and calcareous sandy soil.

Siliceous sandy soil was collected from Abu Roash sand quarry. It is located about $8 \mathrm{~km}$ north of Giza. The gradation and chemical composition of the used sample are shown in Figure $\mathbf{1}$ and Table 1. The sample grain size was medium to fine, with traces of fine gravel. It belonged to the sand of the siliceous type $\left(\mathrm{SiO}_{2}: 96.12 \%\right)$ and it showed medium alkalinity manner, with the lowest chloride content compared to other studied soils.

Silty sand soil was collected from El Mania quarry, located approximately $245 \mathrm{~km}$ south of Cairo on the western bank of the Nile river. The natural soil sample used in this study was fine to medium sand mixed with fines of silt and clay sizes, as shown in Figure 2. According to the physical properties and 
http://wjst.wu.ac.th

chemical composition given in Table 1, the used silty sand sample was composed mainly of silica $\left(\mathrm{SiO}_{2}\right.$ : $95.96 \%$ ) and it was of a medium alkalinity type.

Calcareous sandy soil was collected from the north coast of the Mediterranean Sea, Badr village, about $82.5 \mathrm{~km}$ west of Alexandria and approximately $237 \mathrm{~km}$ northwest of Cairo. The natural calcareous sandy soil used in this study was light brown in color, uncemented, and showed medium to fine sand size (Figure 3). According to the physical properties and chemical composition shown in Table 1, this soil was calcareous ( $\mathrm{CaO}: 50 \%$ ), its alkalinity was medium, and it had the highest chloride content.

Table 1 Physical properties and chemical composition of the used sandy soils.

\begin{tabular}{|c|c|c|c|c|c|c|c|c|}
\hline Soil type & $\begin{array}{l}\text { Specific } \\
\text { gravity }\end{array}$ & $\begin{array}{c}\text { BS } \\
\text { classification }\end{array}$ & pH & $\begin{array}{c}\mathrm{Cl}^{-} \\
(\mathbf{p p m})\end{array}$ & $\begin{array}{l}\mathrm{SiO}_{2} \\
(\%)\end{array}$ & $\begin{array}{c}\mathrm{Fe}_{2} \mathrm{O}_{3} \\
(\%)\end{array}$ & $\begin{array}{c}\mathrm{Al}_{2} \mathrm{O}_{3} \\
(\%)\end{array}$ & $\begin{array}{c}\mathrm{CaCO}_{3} \\
(\%)\end{array}$ \\
\hline Siliceous & 2.88 & Sand & 8.18 & 39.50 & 96.12 & 0.44 & 1.05 & 2.39 \\
\hline Silty & 2.81 & Silty sand & 8.40 & 92.85 & 95.96 & 1.06 & 1.43 & 0.00 \\
\hline Calcareous & 2.77 & Sand & 8.23 & 121.00 & 10.45 & 0.33 & 1.46 & 87.47 \\
\hline
\end{tabular}

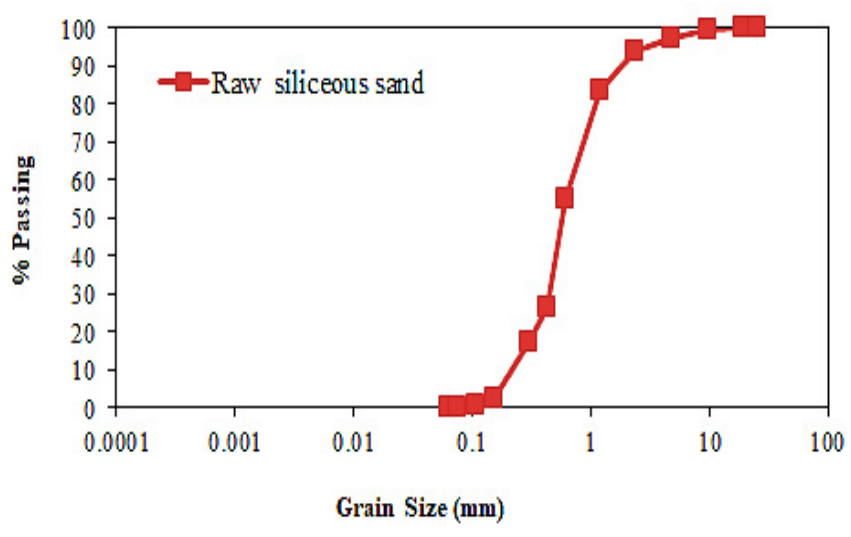

Figure 1 Grain size distribution of raw siliceous sand sample.

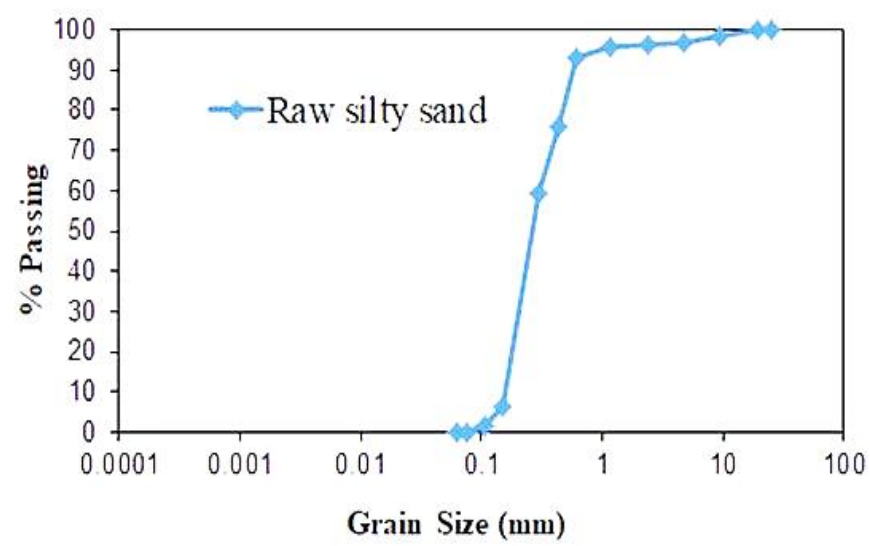

Figure 2 Grain size distribution of raw silty sand sample. 
http://wjst.wu.ac.th

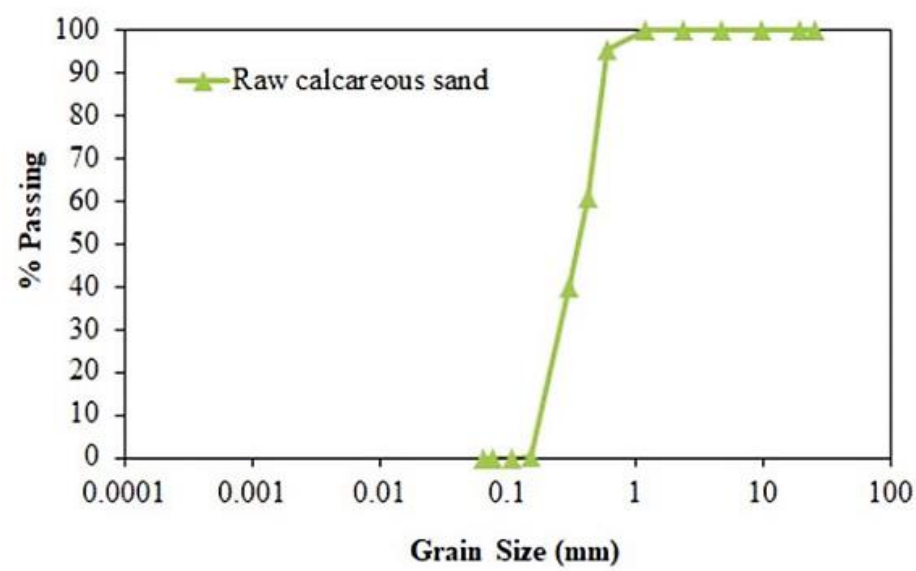

Figure 3 Grain size distribution of raw calcareous sandy sample.

\section{Bacteria strain}

The bacterium was Sporosarcina pasteurii. It was delivered as a powder, purchased from Deutsche Sammlungvan Mikroorganismen und Zellkalturen, Germany, by the National Research Center, Egypt.

\section{Chemicals}

All chemicals used in this study were products of Loba Chemie Company, Mumbai, India. They were purchased from the Egyptian market. The physical and chemical properties are given in Table 2. These chemicals were used to prepare cementation and fixation solutions.

Table 2 Physical and chemical properties of chemical additives used.

\begin{tabular}{lccccc}
\hline Property & Yeast extract & $\begin{array}{c}\text { Anhydrous } \\
\text { calcium } \\
\text { chloride }\end{array}$ & Urea & $\begin{array}{c}\text { Ammonium } \\
\text { chloride }\end{array}$ & $\begin{array}{c}\text { Sodium } \\
\text { hydroxide }\end{array}$ \\
\hline Purity & $60.0 \%$ & $98.0 \%$ & $99.5 \%$ & $99.5 \%$ & $98.0 \%$ \\
Physical state at $20{ }^{\circ} \mathrm{C}$ & Solid & Solid & Solid & Solid & Solid \\
Odor & Characteristic odor & Odorless & Odorless & Odorless & Odorless \\
pH & - & $5-8$ & $7.5-9.5$ & $4.5-5.5$ & $13-14$ \\
Solubility $(\%$ weight $)$ & $20 \%$ in water & $\begin{array}{c}\text { Completely } \\
\text { soluble }\end{array}$ & $\begin{array}{c}\text { Completely } \\
\text { soluble }\end{array}$ & $\begin{array}{c}\text { Completely } \\
\text { soluble }\end{array}$ & $\begin{array}{c}111 \mathrm{~g} / 100 \mathrm{~g} \\
\text { water }\end{array}$ \\
Molecular weight & - & 147.02 & 60.06 & 53.49 & 40.00 \\
Molecular formula & - & $\mathrm{CaCl}_{2} .2 \mathrm{H}_{2} \mathrm{O}$ & $\mathrm{NH}_{2} \mathrm{CONH}$ & $\mathrm{NH} \mathrm{H}_{4} \mathrm{Cl}$ & $\mathrm{NaOH}$ \\
Color & Light brown & White & White & White & White \\
Solid states & Powder & Powder & Crystalline & Crystalline & Pellets \\
Density $\left(\mathrm{gm} / \mathrm{cm}^{3}\right)$ & - & 1.85 & 1.35 & 1.53 & 2.13 \\
\hline
\end{tabular}




\section{Methods}

\section{Preparation of samples}

To prepare the studied sandy soil samples for the experimental tests, a representative dry raw sand sample from each soil type was used. It was reported that the use of biocementation is more effective for dry sand with no water content, which leads to increase in the body strength [6]. So, the sand samples were used as received from the quarries and were dried naturally at an open area in the laboratory under ambient conditions. All the dried sandy samples were placed vertically in glass tubes of internal diameters of 5 and $7.5 \mathrm{~cm}$ and lengths of 15 and $40 \mathrm{~cm}$, respectively. In all tubes, a piece of cotton was placed at the bottom to prevent sand from flowing out. The glass tubes were fastened vertically; then, the sand sample was placed in the tube gently and vibrated to obtain homogeneous distribution, as shown in Figure 4. The prepared solution (as mentioned later) was then added by pouring it on the top surface; then, the solution inside the column moved down naturally under the force of gravity.

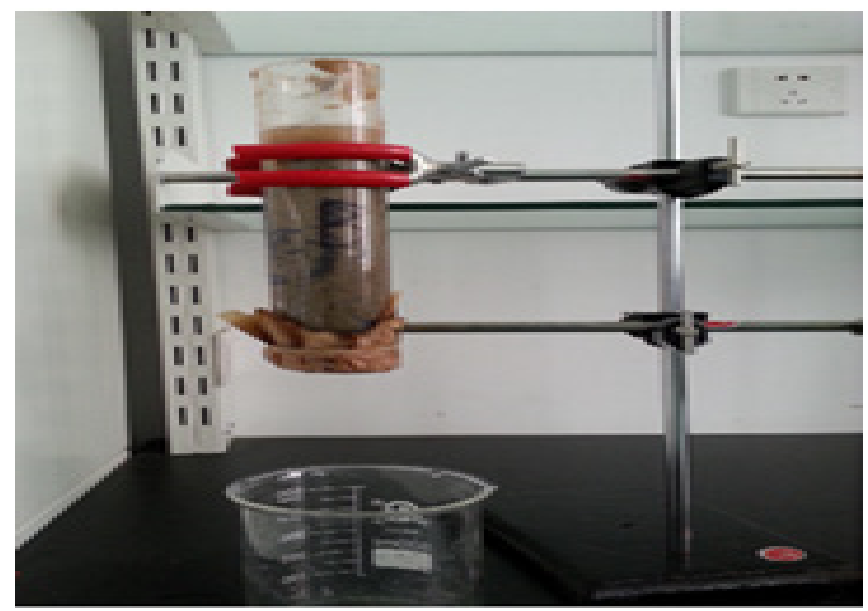

Figure 4 Photograph showing a general view of the setting up of a soil sample for the treatment process.

\section{Preparation of bacteria suspension}

The Sporosarcina pasteurii was cultured in a sterilized medium consisted of $20 \mathrm{~g} / \mathrm{L}$ yeast extract and $10 \mathrm{~g} / \mathrm{L}$ ammonium chloride. The preparation steps were given in details in [33]. After obtaining the bacterial cells, they were poured on the top surface of the prepared soil samples inside the glass tubes.

\section{Preparation of chemical solutions}

In this study, 2 solution types were used; cementation and fixation, to initiate stabilization reactions. The cementation solution was prepared by mixing $1 \mathrm{~mol}(60.06 \mathrm{~g} / \mathrm{L})$ of urea and $1 \mathrm{~mol}(147.02 \mathrm{~g} / \mathrm{L})$ of anhydrous calcium chloride, all dissolved in $2 \mathrm{~L}$ of distilled water. The fixation solution was prepared by the addition of $0.05 \mathrm{~mol}(7.35 \mathrm{~g} / \mathrm{L})$ of anhydrous calcium chloride in $1 \mathrm{~L}$ of distilled water.

\section{Biocementation process}

Bacteria, urea, and calcium chloride were used as primary materials in the biocementation process. The effect of the added urea and calcium chloride on the process of the enzymatic calcium carbonate precipitation was studied through 2 experimental stages. The $1^{\text {st }}$ was carried out at the test-tube stage containing cementation solution and bacteria without soils to achieve the best mixing ratio that formed the highest content of precipitated calcium carbonate. The $2^{\text {nd }}$ stage was conducted using the soils with the most promising mixing ratio obtained from the $1^{\text {st }}$ stage with the addition of fixation solution to stabilize the sandy soils effectively. 
http://wjst.wu.ac.th

\section{Test tube experiments}

A series of tests was performed in order to determine the best mixing ratio between the bacteria and the cementation solution which gave the highest amount of calcium carbonate. For this purpose, bacterial cells of varied concentrations were mixed with urea- $\mathrm{CaCl}_{2}$ (cementation solution). The amount of cementation solution used in all the tests was a constant $8 \mathrm{~mL}$ (Table 3). The precipitated $\mathrm{CaCO}_{3}$ settled at the bottom of the test tubes was calculated visually using a ruler after $24 \mathrm{~h}$.

Table 3 Mixes of different concentrations of the used bacteria.

\begin{tabular}{cccc}
\hline Tube & Bacteria $(\mathbf{m L})$ & Tube & Bacteria $(\mathbf{m L})$ \\
\hline 1 & 0.5 & 6 & 3.0 \\
2 & 1.0 & 7 & 3.5 \\
3 & 1.5 & 8 & 4.0 \\
4 & 2.0 & 9 & 4.5 \\
5 & 2.5 & 10 & 5.0 \\
\hline
\end{tabular}
samples

Bacterial cell, fixation, and cementation solution (BFC) concentrations mixed with siliceous sand

In order to investigate the effect of the mix combinations of bacterial cells, fixation, and cementation solution (BFC) for the stabilization of siliceous sand sample, 4 mixes, namely, IF1, IF2, IF3, and IF4, were designed (Table 4) to determine the best ratio of the ingredients based on the test results of physico-mechanical properties.

Table 4 Mix combinations of siliceous sand soil sample.

\begin{tabular}{ccccc}
\hline $\begin{array}{c}\text { Sample } \\
\text { code }\end{array}$ & $\begin{array}{c}\text { Soil weight } \\
(\mathbf{g})\end{array}$ & $\begin{array}{c}\text { Bacterial cells } \\
(\mathbf{m L})\end{array}$ & $\begin{array}{c}\text { Fixation solution } \\
(\mathbf{m L})\end{array}$ & $\begin{array}{c}\text { Cementation solution } \\
(\mathbf{m L})\end{array}$ \\
\hline IF 1 & 40 & 8 & 8 & 80 (1bacterai: 10 cementation) \\
IF 2 & 40 & 12 & 12 & 84 (1bacterai: 7 cementation) \\
IF 3 & 40 & 16 & 16 & 80 (1bacterai: 5 cementation) \\
IF 4 & 40 & 24 & 24 & 144 (1bacterai: 6 cementation) \\
\hline
\end{tabular}

\section{Optimum ratio of BFC at different times number of additions on the used soils}

In this stage, siliceous, silty, and calcareous sandy samples were treated by pouring $8 \mathrm{~mL}$ of bacterial cells on $40 \mathrm{~g}$ of different soils samples. The mix combinations, including the BFC at different times number of additions, are shown in Table 5. This was to explore the effectiveness of the bio stabilization process on the soil samples of different porosities. The amount of cementation solution was 10 times that of the bacterial cells. The amount of fixation solution was equal to the bacterial cells in the siliceous sand and silty sand samples, while this percentage was changed to 1 bacterial cells: 2 fixation solution in the calcareous sandy sample. This resulted in increasing the discharge rate and decreasing the staying time of the BFC solution in the calcareous sample compared with that of the status of the sand and silty sand samples. The calcareous soil required a high amount of fixation solution for filling the pores and increasing the staying time within the sample, which led to increase in the action time between the added ingredients to give well-adhered soil granules. 
http://wjst.wu.ac.th

\section{Testing}

After ending the biocementation process, a series of tests was carried out on the biocemented samples of different soil types in order to determine the engineering properties in terms of stability in water, permeability, unconfined compressive strength, direct shear, slake durability index test, and determination of calcium carbonate content. These tests were described in detail [33]. Also, X-ray diffraction technique (XRD) was used to characterize the mineralogical phases. The XRD apparatus was X' Pert PRO PW3040/6 (PANalytical) diffractometer equipped with a monochromatic $\mathrm{Cu}-\mathrm{K} \alpha$ radiation source. The test was run at $40 \mathrm{kV}$ and $30 \mathrm{~mA}$. The acquired data was identified using $\mathrm{X}^{\prime}$ Pert high score software works with a PDF-2 database. The XRD test was carried out for the raw and biocemented samples.

The chemical composition (major oxides) of the used raw sample was determined by X-ray fluorescence (XRF) using an Axios sequential spectrometer manufactured by PANalytical, Netherlands. Scanning electron microscopy (SEM) was used to characterize raw and biocemented samples (PHILIPS, XL20 Scanning Electron Microscope, Eindhoven, Netherlands).

\section{Results and discussion}

\section{Effect of BFC concentrations on the stabilization of siliceous sand soil}

Test tube mixes without soil samples

Figure 5 illustrates the effect of mixing of varied 10 concentrations of bacterial solutions with a constant amount of cementation solution $(8 \mathrm{~mL})$ on the amount of carbonate formed. The results showed that the low bacterial cells concentration $(0.5-1.0 \mathrm{~mL})$ induces a reduction in the efficiency of the formation process where a low amount of $\mathrm{CaCO}_{3}$ is formed as a suspension, as shown in the mixes 1 and 2 (Figure 5). This means that a part of urea is not hydrolyzed by the urease. This behavior may be due to the insufficient quantity of the urease enzyme and/or due to a negative effect of the high urea-CaCl 2 concentration $(8 \mathrm{~mL})$, which may have inhibited the action of urease. Consequently, the bio-stabilization process is less effective. This is consistent with the views of other authors $[34,35]$ who recorded that high $\mathrm{CaCl}_{2}$-urea concentration is related to the amount of urease and may restrain the activity of urease, which may in turn result in a reduction in calcium carbonate precipitation.

Table 5 Mixes of soil samples treated by the BFC at different times number of additions.

\begin{tabular}{lccccc}
\hline Sample code & $\begin{array}{c}\text { Soil weight } \\
(\mathbf{g})\end{array}$ & $\begin{array}{c}\text { Bacterial cells } \\
(\mathbf{m L})\end{array}$ & $\begin{array}{c}\text { Fixation } \\
\text { solution } \\
(\mathbf{m L})\end{array}$ & $\begin{array}{c}\text { Cementation } \\
\text { solution } \\
(\mathbf{m L})\end{array}$ & $\begin{array}{c}\text { Number of } \\
\text { additions }\end{array}$ \\
\hline $\begin{array}{l}\text { Optimum } \\
\text { mix ratio }\end{array}$ & 40 & 8 & 8 & 80 & 1 \\
Siliceous sand & & & & & \\
IF5 & 500 & 100 & 100 & 1000 & 1 \\
IF6 & 1000 & 200 & 200 & 2000 & 4 \\
IF7 & 1000 & 200 & 200 & 2000 & 7 \\
Silty sand & & & & & 1 \\
IF8 & 275 & 55 & 55 & 550 & 7 \\
IF9 & 1000 & 200 & 200 & 2000 & 4 \\
IF10 & 1000 & 200 & 200 & 2000 & 6 \\
Calcareous sand & 1000 & 200 & 400 & 2000 & 1 \\
IF11 & 1000 & 200 & 400 & 2000 & \\
IF12 & & & & & \\
\hline
\end{tabular}


http://wjst.wu.ac.th

Also, the results showed that the amount of precipitated $\mathrm{CaCO}_{3}$ increased as the concentration of bacteria $(1.5-3 \mathrm{~mL})$ increased, as shown in the test tubes 3 to 6 . This means that the amount of urease in the solution was able to hydrolyze almost all the urea.

In the other test tubes ( 7 to 10 ) of bacteria concentrations from $3.5-5.0 \mathrm{~mL}$, a part of bacteria was suspended as a brown turbidity color, and also calcium carbonate content was noticed at the bottom. This means that the amount of urea existing in the solution was lower than the amount of urease (Figure 5), which led to loss in the quantity of the enzyme and limited the benefits. These results indicated that the increase in the quantity of bacteria to the amount of cementation solution gave incomplete utilization of bacteria, while the amount of urea in the cementation solution was insufficient for the amount of the enzyme produced by bacteria. This increases the bio-cementation cost without increasing the amount of calcite precipitation, which makes the process ineffective and uneconomic, as obviously noticed from the results of the test tubes from $7-10$.
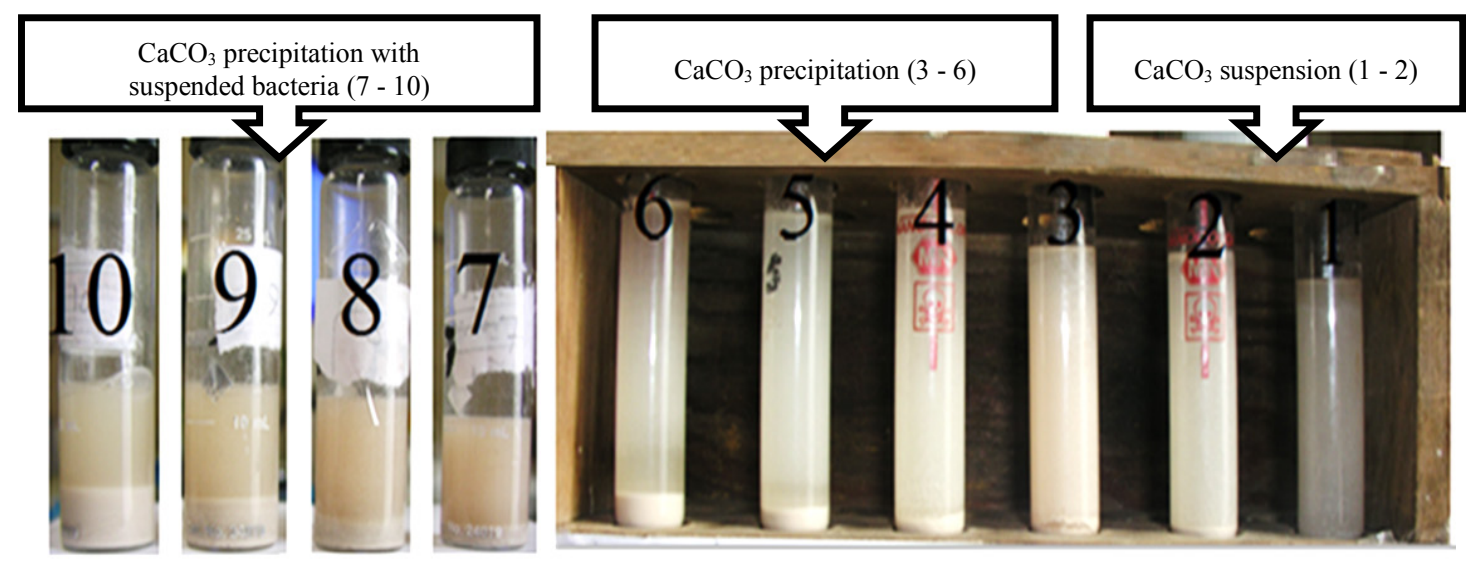

Figure 5 Status of the formed $\mathrm{CaCO}_{3}$ after $24 \mathrm{~h}$.

Physico-mechanical properties of siliceous sand samples treated by different BFC concentrations

The best bacterial solution concentrations between $1.5-3 \mathrm{~mL}$ was added on siliceous samples at different BFC concentrations and were evaluated physico-mechanically as follows:

\section{Unconfined compressive strength}

Figure 6 showed the unconfined compressive strength results of siliceous sand samples treated by different concentrations of BFC solutions. The results revealed that the maximum value was $4.9 \mathrm{~kg} / \mathrm{cm}^{2}$, while the lowest value was $3.0 \mathrm{~kg} / \mathrm{cm}^{2}$ for mixes IF1 and IF2, respectively. Meanwhile the compressive strength values of 4.8 and $4.0 \mathrm{~kg} / \mathrm{cm}^{2}$ were for IF 4 and IF 3 mixes, respectively. As the concentration of cementation solution increased accompanied with a suitable content of bacterial concentration, the compressive strength increased (IF1).

Although quantities of the bacteria used in the sample of mix IF 4 were 3 times more than the quantity used in the sample of mix IF1, the compressive strength values of the sample of mix IF1 was the highest. This is probably due to the increase in the amount of bacteria that produced a high content of the enzyme urease, which required a high amount of cementation solution to consume the content of the produced enzyme. Also, the increase in the amount of the cementation solution provided a large amount of urea (urea is the substance of the enzyme).

To achieve benefits in the IF4 mix, more cementation solution was needed. Similarly, the quantity of bacteria used in the mix IF3 was twice the quantity used in the sample of mix IF1. However, the values of the compressive strength values in mix IF1 were higher than the mix IF3. This is because the ratio of 
http://wjst.wu.ac.th

cementation solution to bacteria in the sample of mix IF1 was twice that of mix IF3. In the sample of mix IF2, the quantity of bacteria used was one and half times more than that used in mix IF1.

The compressive strength values in mix IF1 were higher than in mix IF2. This is attributed to the ratio of cementation solution to bacteria in mix IF2 (7:1) being less than that in mix IF1 (10:1). It is worth noting that the ratio of cementation solution to bacteria suspension had an important effect on increasing the stiffness of the samples. If the amount of cementation solution is unsuitable to the amount of bacteria, as shown in IF2, IF3, and IF4, this will dramatically decrease the bacterial activity and increase the cost without a remarkable increase in the hardness of the sample.

Finally, the best mix ratio that could be used to obtain the highest compressive strength value was 1 bacterial cell: 1 fixation solution: 10 cementation solution of mix IF1.

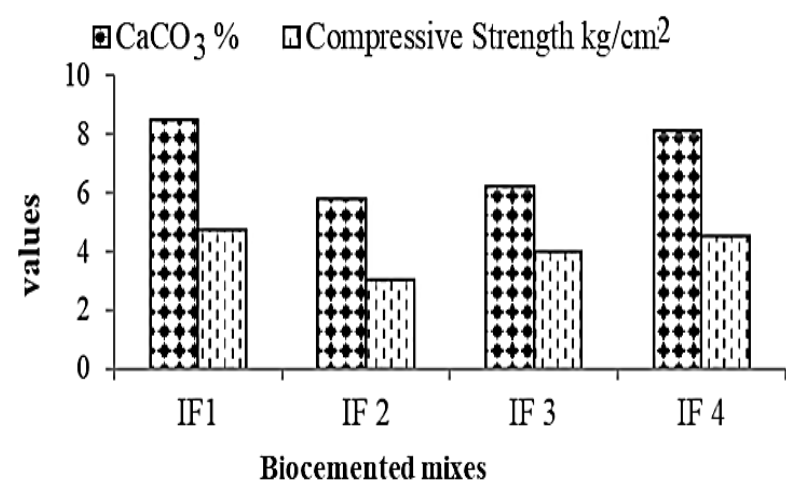

Figure 6 Relationship between the precipitated calcium carbonate and compressive strengths of different mixes for siliceous sand samples.

Calcium carbonate content and mineralogy of siliceous sand sample

Calcium carbonate content of the studied mix combinations of siliceous sand samples is recorded in Table 6. Due to the action of BFC of different combination ratios, the content of the formed $\mathrm{CaCO}_{3}$ was increased in all mixes compared to the raw sample $(2.5 \%)$. Furthermore, the content of the formed carbonate could be arranged in descending order as follows: mix IF1 (8.5\%), mix IF4 (8.1\%), mix IF3 $(6.2 \%)$, and mix IF2 (5.8\%).

Table 6 Calcium carbonate content (\%) of different mix combinations of siliceous sand soil samples.

\begin{tabular}{cc}
\hline Samples code & $\mathbf{C a C O}_{\mathbf{3}}(\mathbf{\%})$ \\
\hline IF1 & 8.5 \\
IF 2 & 5.8 \\
IF 3 & 6.2 \\
IF 4 & 8.1 \\
\hline
\end{tabular}

Figure 7 shows the XRD patterns of the raw sand sample used and its biocemented sample of mix IF1. As shown from the XRD patterns, the main found phases were well crystallized quartz and calcite of poorly crystalized form, meaning a clear progress in calcite formation (1F1) by the bacterium activity. The results showed that the semi quantitative percentage of calcite increased from the raw sand $(2.5 \%)$ to the biocemented sample of mix IF1 $(6.4 \%)$. This is obviously due to the action of BFC, which 
http://wjst.wu.ac.th

precipitated more calcite. Also, quartz peak intensity were decreased in the sample of mix IF1. This may be attributed to the quartz grain size changes due to the particle agglomeration after the biocementation or treatment process, as confirmed by the authors [36].

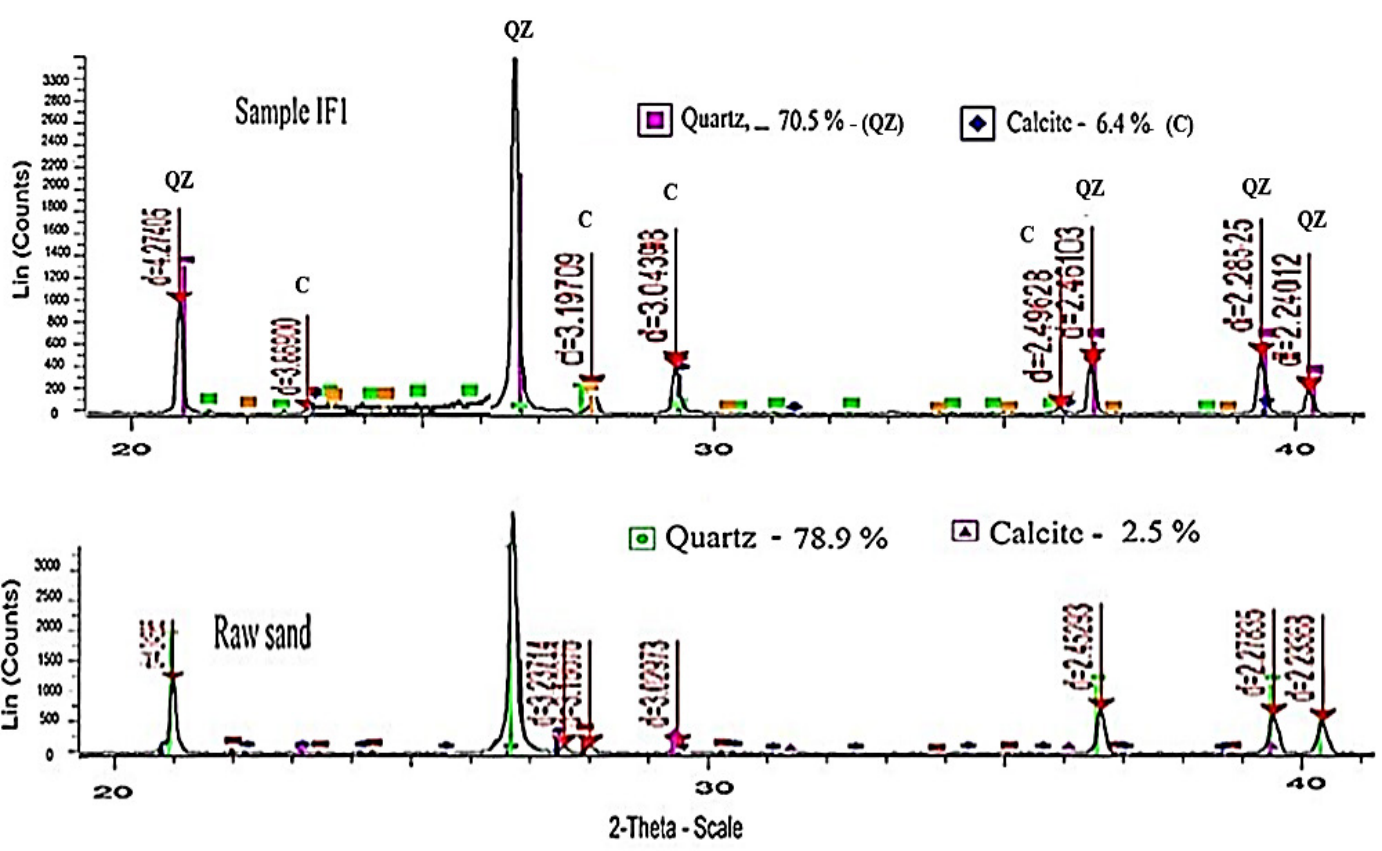

Figure 7 XRD patterns of raw sand and its biocemented sample of mix IF1 and their semi quantitative (S.Q.) percentages of the detected minerals.

Effect of the most promising BFC ratio at different times number of additions on the stabilization of the used soils

Stability of biocemented sand samples in water

Figure 8 shows the results of stability of the different mixes in water. Visually, all the samples had no deleterious appearance. This means that the number of additions of the solution had no significant effect on the results of the stability of soil samples in water. However, the results showed a stability improvement for the body of biocemented tested samples by using the ureolytic bacteria of the number of additions of the solution. 
http://wjst.wu.ac.th
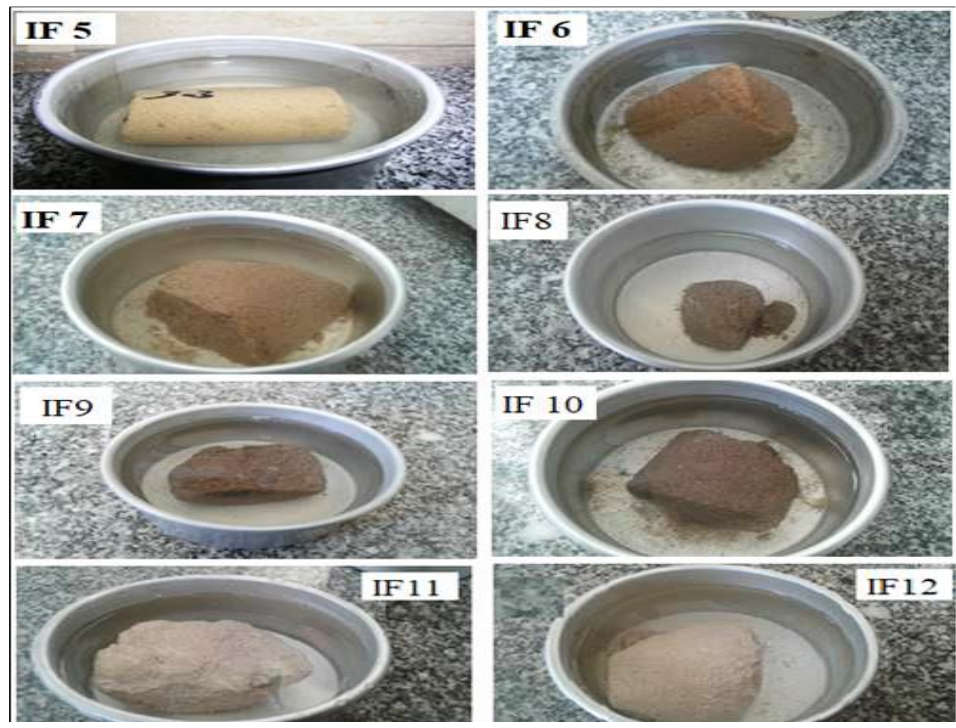

Figure 8 Photographs showing results of stability in water for the biocemented sand samples of different mixes after immersion in tap water for $24 \mathrm{~h}$.

\section{Calcium carbonate content}

The percentages of the total calcite, found naturally and formed during the bio-cementation process, in the biocemented siliceous, silty, and calcareous sand samples which were treated by BFC for different times of additions, are tabulated in Table 7. In siliceous sand samples, the calcium carbonate values could be arranged in descending order as follows: Sample of mix IF7 (15.17\%) treated with 7 additions, followed by sample of mix IF6 (12.76 \%), then sample of mix IF5 (9.39\%).

The treated silty sand sample showed the highest content of precipitated $\mathrm{CaCO}_{3}(19.18 \%)$ at mix IF10, which was treated by BFC solution 4 times. The results of the calcareous sample showed that the highest content of total $\mathrm{CaCO}_{3}$ was noticed in mix IF11 (93.5\%), which was treated with 6 additions.

Table 7 Results of $\mathrm{CaCO}_{3}$ content determination and slake durability index of biocemented samples of different mixes treated by BFC solution.

\begin{tabular}{cccc}
\hline \multirow{2}{*}{ Sample code } & \multicolumn{2}{c}{ Total $\mathrm{CaCO}_{3}$ for the samples \% } & Slake durability index (\%) \\
\cline { 2 - 3 } & \multirow{2}{*}{ Raw } & Biocemented & \\
\hline IF5 & \multirow{2}{*}{2.50} & 9.39 & Not available \\
IF6 & & 12.76 & 45 \\
IF7 & \multirow{2}{*}{0.00} & 15.17 & 47 \\
\hline IF8 & & 12.78 & Not \\
IF9 & \multirow{2}{*}{87.47} & 19.18 & 45 \\
IF10 & 93.50 & 46 \\
\hline IF11 & 90.30 & 43 \\
IF12 & & 40 \\
\hline
\end{tabular}




\section{Unconfined compressive strength}

Figure 9 shows the results of the unconfined compressive strength test of biocemented samples of different soils. The results indicated that the number of additions clearly affected the compressive strength results. The siliceous sand sample showed that the maximum compressive strength was $17.73 \mathrm{~kg} / \mathrm{cm}^{2}$ for 7 additions, and the lowest value $\left(5.97 \mathrm{~kg} / \mathrm{cm}^{2}\right)$ was observed for 1 time of addition. This may be attributed to the fact that the increase in the number of additions gave more time for the reagent to stay inside the sample to produce the reaction and increase calcite content within the sample column, consequently helping to bind the soil granules. Due to the high discharge rate in siliceous sand soil, the best results were found for the sample treated by BFC for 7 additions.

In the silty sand sample, the maximum compressive strength value was $15.28 \mathrm{~kg} / \mathrm{cm}^{2}$ for the sample treated for 4 times of additions (IF10), while it was $5.1 \mathrm{~kg} / \mathrm{cm}^{2}$ for 1 time of addition (IF8). The compressive strength value of $11.33 \mathrm{~kg} / \mathrm{cm}^{2}$ was achieved for 7 additions in mix IF9. This is due to this type of soil having a low discharge rate, and the high addition times may keep the solution inside the sample column for a long time, hindering the reaction between the bacteria and $\mathrm{FC}$ solution, preventing $\mathrm{CaCO}_{3}$ precipitation; but, in the case of the sample of mix IF8, it may have needed more time to precipitate enough amount of calcite.

In the calcareous sample, the maximum compressive strength was $11.49 \mathrm{~kg} / \mathrm{cm}^{2}$ for 6 additions of solution addition, while it was $9.33 \mathrm{~kg} / \mathrm{cm}^{2}$ when the sample was treated by BFC for a single addition, as illustrated in Figure 9. As the number of additions increased, the compressive strength values increased, with the same trend of the sample of siliceous mix. This is because this type of soil has a high drainage rate, as observed during the experimental work, leading to increase in the probability of ejecting the solution outside the sample column quickly without proceeding to the the reaction. Therefore, using a low number of additions will decrease the amount of calcite precipitation among soil granules, so a high number of BFC additions are needed.

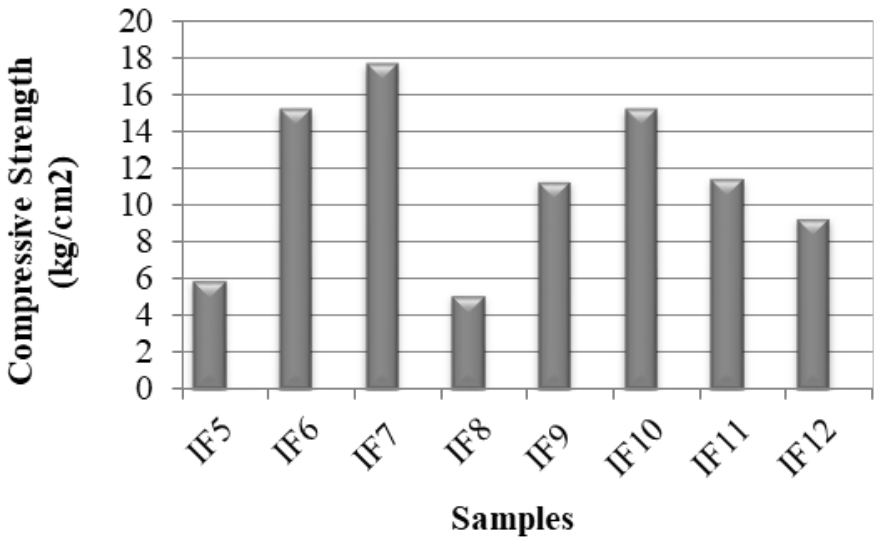

Figure 9 Unconfined compressive strength of biocemented mixes of siliceous sand (IF5 - IF7), silty sand (IF8 - IF10), and calcareous sand (IF11 - IF12)

\section{Slake durability index (SDI)}

Table 7 above shows the results of the SDI test for the biocemented samples of siliceous sand, silty sand, and calcareous sandy soils. This test was nor performed on samples of mixes IF5 or IF8 due to lack of material. The test results indicated that all samples after immersion in tap water for $24 \mathrm{~h}$ were durable. The precipitation of the calcite formed by the BFC performed as a binder for the sand grains in the samples, which increased the resistance to the deterioration due to friction forces during the movement in the test. The use of the biocementation process improved the mechanical properties of the soil samples and their resistance to degradation. The highest SDI values were found in samples of mixes IF7, IF10, 
http://wjst.wu.ac.th

and IF11 treated by BFC for 7, 4, and 6 additions for siliceous sand, silty sand, and calcareous sand soils, respectively.

\section{Direct shear}

Table 8 shows the friction angle and cohesion values for the raw sandy samples and biocemented siliceous sand, silty sand, and calcareous sand samples which were treated by BFC. This test was not applied to samples of mixes IF5 or IF8 due to lack of material. The results revealed that, in case of siliceous and calcareous samples, as the number of additions of BFC increased, the results of direct shear increased. So, the samples that were treated for 7 and 6 times had the best results for the siliceous and calcareous samples, respectively. Contrariwise, silty sand samples had the best results of direct shear at 4 times of BFC addition rather than 7 times, which is enough to the sample to be cemented.

In all the cases, the friction angles and cohesion of the samples improved after the biocementation. This confirms that the precipitated calcite acted well as a cementing material, as supported by the author [36]. Furthermore, the increase of friction angles and cohesion of the biocemented samples were reflected in the increase of shear strength values [37].

\section{Permeability}

The results of the permeability test are given in Table 8. With the same trend of direct shear results, in the siliceous sand sample, the lowest permeability value $(1.22 \mathrm{E}-05 \mathrm{~cm} / \mathrm{s})$ was obtained by using BFC for 7 additions, while in silty sand, the minimum permeability of $5.71 \mathrm{E}-06 \mathrm{~cm} / \mathrm{s}$ was obtained for 4 additions, and in the calcareous sand sample, the permeability was $4.65 \mathrm{E}-04 \mathrm{~cm} / \mathrm{s}$ for 6 additions. The tested properties of biocemented sand samples were affected by the content of precipitated calcium carbonate. The higher the calcium carbonate and the shear and compressive strengths, the lower permeability and the higher the durability.

Table 8 Cohesion (c) and friction angle $(\varphi)$ parameters for the raw soil samples and biocemented samples treated by BFC solution.

\begin{tabular}{|c|c|c|c|c|c|}
\hline \multirow[t]{2}{*}{ Sample code } & $\begin{array}{c}\text { Friction } \\
\text { angle - } \Phi \\
\text { (Deg) }\end{array}$ & $\begin{array}{c}\text { Cohesion - C } \\
\left(\mathrm{kg} / \mathrm{cm}^{2}\right)\end{array}$ & $\begin{array}{c}\text { Friction } \\
\text { angle - } \Phi \\
\text { (Deg) }\end{array}$ & $\begin{array}{c}\text { Cohesion - C } \\
\quad\left(\mathrm{kg} / \mathrm{cm}^{2}\right)\end{array}$ & \multirow[t]{2}{*}{$\begin{array}{c}\text { Permeability } \\
\mathrm{cm} / \mathrm{s}\end{array}$} \\
\hline & \multicolumn{2}{|c|}{ dry } & \multicolumn{2}{|c|}{ wet } & \\
\hline Raw siliceous sand & 36 & 0.00 & 36 & 0.01 & $1.04 \mathrm{E}-03$ \\
\hline IF6 & 39 & 5.85 & 42 & 5.87 & 4.35E-05 \\
\hline IF7 & 40 & 7.14 & 43 & 7.19 & $1.22 \mathrm{E}-05$ \\
\hline Raw silty sand & 32 & 0.03 & 32 & 0.04 & 4.17E-05 \\
\hline IF9 & 34 & 4.11 & 38 & 4.19 & 7.24E-06 \\
\hline IF 10 & 35 & 5.71 & 39 & 5.75 & $5.71 \mathrm{E}-06$ \\
\hline Raw calcareous sand & 28 & 0.01 & 28 & 0.03 & $0.75 \mathrm{E}-03$ \\
\hline IF11 & 37 & 7.25 & 39 & 7.27 & $4.65 \mathrm{E}-04$ \\
\hline IF12 & 35 & 5.90 & 38 & 6.23 & Not detected \\
\hline
\end{tabular}

\section{Scanning electron microscopy (SEM)}

Figures 10 - 12 show the SEM images of the biocemented samples of the most promising mixes of IF7, IF10, and IF11 belonging to the siliceous, silty, and calcareous soils, respectively. In the sample of mix IF7, the SEM images show a number of open pores that sometimes filled with the formed cementing material. Also, the matrix showed a heterogeneous distribution of the formed $\mathrm{CaCO}_{3}$ that appeared as clusters and rod-like shaped particles found in the open pores and between the sand grains and on the grain surfaces (Figure 10). In the sample of mix IF10, the SEM images showed the presence of precipitated calcium carbonate with a small number of open pores and good bonded grains due to the 
http://wjst.wu.ac.th

effect of soil composition (silty sand of fine grains) and the formed cementing material. The SEM images (Figure 11) of the silty sand sample show that the formed cementing material $\left(\mathrm{CaCO}_{3}\right)$ filled the present pores. This material showed good distribution and appeared as agglomerated clusters at all places in the sample matrix.

Morphologically, the SEM images of the biocemented sample of mix IF11 that referred to calcareous sandy soil exhibited a well-cemented pattern. Sand grains of a semi-rounded shape were almost coated by the formed $\mathrm{CaCO}_{3}$. Also, it was observed that the formed calcite appeared as a network form and was mostly well-distributed in the matrix (Figure 12).

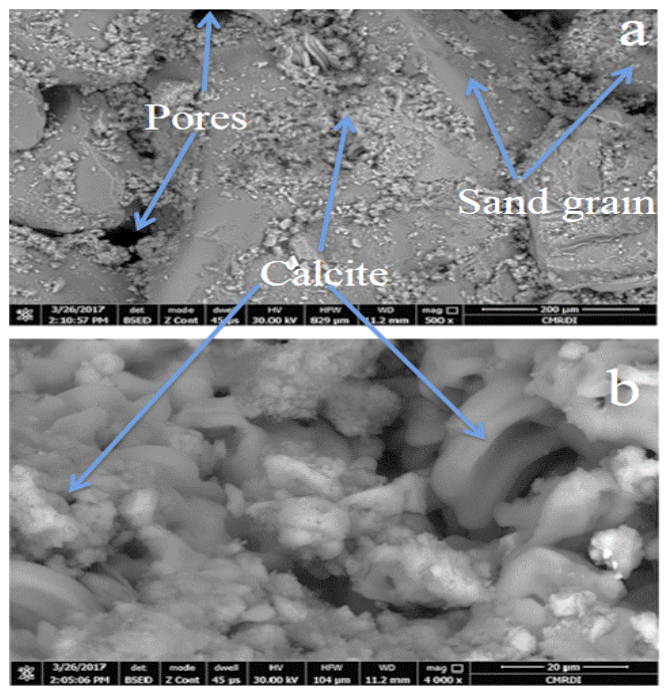

Figure 10 SEM micrographs of biocemented sample of mix IF7 showing (a) calcite distribution and features found in the siliceous sand matrix; (b) the shape of the formed calcite.

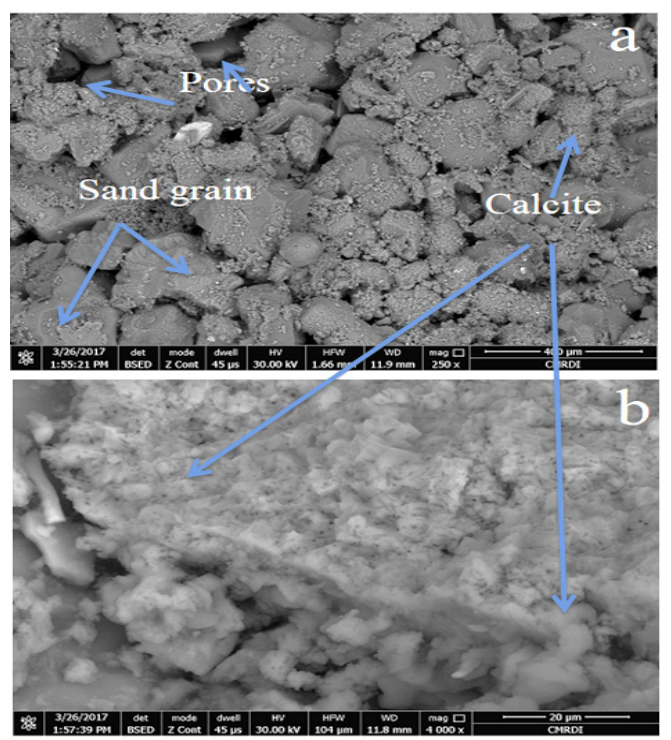

Figure 11 SEM micrographs of biocemented sample of mix IF10 showing (a) calcite distribution and features in the matrix; (b) the shape of the formed calcite. 
http://wjst.wu.ac.th

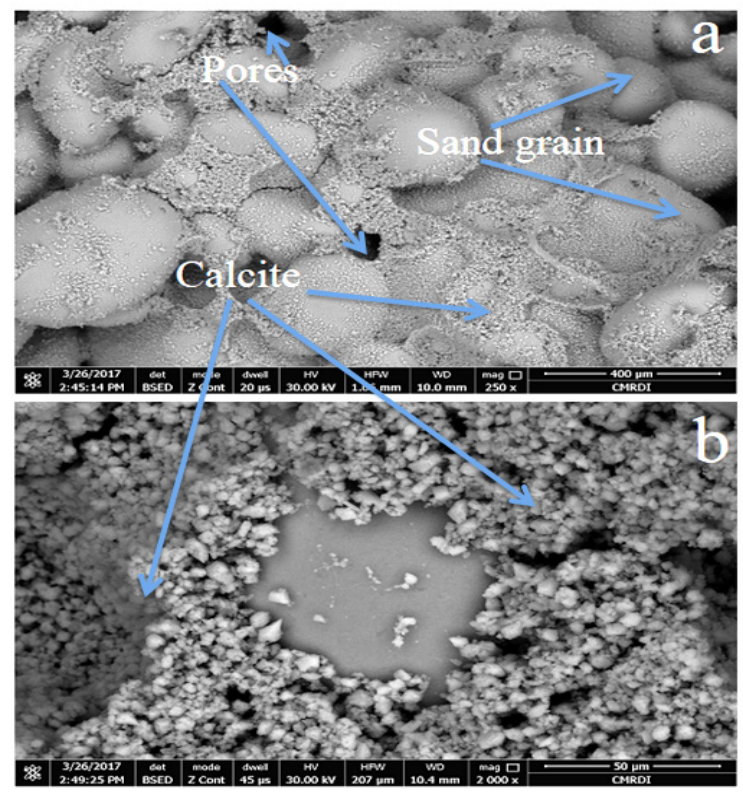

Figure 12 SEM micrographs of biocemented sample of mix IF11 showing (a) calcite distribution and features in the matrix; (b) the network shape of the formed calcite.

\section{Conclusions}

This research studied the effect of the biocementation process using bacteria-fixation-cementation solution (BFC) at different numbers of additions on siliceous sand, silty sand, and calcareous sandy soils. A series of laboratory physico-chemical and mechanical tests was conducted to explore the improvements in the strength and durability of different sand samples using different testing methods and techniques.

The results indicated that the used bacteria, S. pasteurii, plays a significant role in increasing the compressive strength and durability and in reducing the permeability of biocemented soil samples due to the formation of calcium carbonate by the bacterial activity. Also, the obtained test results showed that the used BFC at suitable addition times has a significant effect on the stabilization of soil samples, where the best results were obtained for the biocemented siliceous sand sample using BFC at 7 times number of additions, for biocemented silty sand sample at 4 times number of additions, and for biocemented calcareous sand sample at 6 times number of additions.

In addition, the test results were affected by the discharge rate of the $\mathrm{BFC}$ and the staying time inside the soils, where the suitable discharge rate gave a sufficient time to proceed the reaction and precipitate a sufficient content of $\mathrm{CaCO}_{3}$ as a cementing material. The results also proved that the precipitation of calcite by the bacterial activity led to the cohesion of soil grains, and this increased the resistance of soils to deterioration. In addition, the high content of the precipitated calcium carbonate enhanced the shear strength and the unconfined compressive strength and decreased the soil permeability. The results of microstructure and $\mathrm{CaCO}_{3}(\%)$ confirmed that a new additional calcite was formed and precipitated between soil grains, leading to connecting the grains.

The usage of the S. pasteurii bacteria method in the soil treatment should be encouraged in Egypt, where this application has many eco, commercial, and engineering advantages. 
http://wjst.wu.ac.th

\section{References}

[1] ME ElMashad and NM Hafez. Sand biogrouting through the deposition of calcium carbonate by ureolytic bacteria. J. Sci. Eng. Res. 2017; 7, 377-82.

[2] G Makusa. 2012, Soil stabilization methods and material. Ph.D. Thesis. Luleå University of Technology, Luleå, Sweden.

[3] MS El-Mahllawy and AM Kandeel. Engineering and mineralogical characteristics of stabilized unfired montmorillonitic clay bricks. HBRC J. 2014; 10, 82-91.

[4] CC Ikeagwuani and DC Nwonu. Emerging trends in expansive soil stabilisation: A review. J. Rock Mech. Geotech. Eng. 2019; 11, 423-40.

[5] C Sirivitmaitrie, AJ Puppal, S Saride and L Hoyos. Combined lime-cement stabilization for longer life of low-volume roads. Transport. Res. Rec. J. Transport. Res. Board 2011; 2204, 140-7.

[6] F Jawad and $\mathrm{J}$ Zheng. Improving poorly graded fine sand with microbial induced calcite precipitation. Br. J. Appl. Sci. Tech. 2016; 17, 1-9.

[7] E Mutaz, MA Shamrani, AJ Puppala and MA Dafalla. Evaluation of chemical stabilization of a highly expansive clayey soil. J. Transport. Res. Board 2011; 2204, 148-57.

[8] S Kazemian, B Huat, AJ Prasad and MA Barghchi. A review of stabilization of soft soils by injection of chemical grouting. J. Appl. Sci. Res. 2010; 6, 5862-8.

[9] V Ivanov and J Chu. Applications of microorganisms to geotechnical engineering for bioclogging and biocementation of soil in situ. Rev. Environ. Sci. Biotechnol, 2008; 7, 139-53.

[10] LAV Paassen, MP Harkes, GV Zwieten, WVD Zon, WVD Star and MV Loosdrecht. Scale up of bioGrout: A biological ground reinforcement method agrandissement de bioGrout: Méthode biologique pour la consolidation des sols. In: Proceedings of the $17^{\text {th }}$ International Conference on Soil Mechanics and Geotechnical Engineering, Alexandria, Egypt. 2009, p. 2328-33.

[11] MP Harkes, LAV Paassen, JL Booster, VS Whiffin and MCMV Loosdrecht. Fixation and distribution of bacterial activity in sand to induce carbonate precipitation for ground reinforcement. Ecol. Eng. 2010; 36, 112-7.

[12] H Rong and CX Qian. Development of microbe cementitious material in China. J. Shanghai Jiaotong Univ. (Sci.) 2012; 17: 350-5.

[13] V Achal, M Li and Q Zhang. Biocement, A recent research in construction engineering: Status of China against rest of world. Adv. Cement Res. 2013; 26, 281-91.

[14] JM Whitaker, S Vanapalli and D Fortin. Improving the strength of sandy soils via ureolytic $\mathrm{CaCO}_{3}$ solidification by Sporosarcina ureae. Biogeosciences 2018; 15, 4367-80.

[15] V Achal, A Mukherjee, PC Basu and MS Reddy. Strain improvement of Sporosarcina pasteurii for enhanced urease and calcite production. J. Ind. Microbiol. Biotechnol. 2009; 36, 981-8.

[16] ND Belie and WD Muynck. Concrete repair, rehabilitation and retrofitting II. In: MG Alexander, HD Beushausen, F Dehn and P Moyo (Eds.). Crack repair in concrete using biodeposition. $1^{\text {st }}$ ed. CRC Press, Florida, 2009, p. 291-2.

[17] J Wang, KV Tittelboom, ND Belie and W Verstratete. Use of silica gel or polyurethane immobilized bacteria for self-healing concrete. Construct. Build. Mater. 2012; 26, 532-40.

[18] JT DeJong, BM Mortensen, BC Martinez and DC Nelson. Bio-mediated soil improvement. Ecol. Eng. 2010; 36, 197-210.

[19] S Stocks-Fischer, JK Galinat and SS Bang. Micro-biological precipitation of $\mathrm{CaCO}_{3}$. Soil Biol. Biochem. 1999; 31, 1563-71.

[20] P Harkes, J Booster, LV Paassen, and MV Loosdrecht. 1D-modelling of microbially induced calcite precipitation for geotechnical applications. In: Proceedings of the $1^{\text {st }}$ International Conference on Bio-Geo-Civil Engineering, Netherlands. 2008, p. 37-41.

[21] AM Sharaky, NS Mohamed, ME Elmashad and NM Shredah. Application of microbial biocementation to improve the physico-mechanical properties of sandy soil. Construct. Build. Mater. 2018; 190, 861-9.

[22] SS Bang, JK Galinat and V Ramakrishnan. Calcite precipitation induced by polyurethaneimmobilized Sporosarcina pasteurii. Enzym. Microb. Tech. 2001; 28, 404-9. 
http://wjst.wu.ac.th

[23] SK Ramachandran, V Ramakrishnan and SS Bang. Remediation of concrete using microorganisms. ACI Mater. J. 2001; 98: 3-9.

[24] P Ghosh, S Mandal, BD Chattopadhyay and S Pal. Use of microorganism to improve the strength of cement mortar. Cement Concr. Res. 2005; 35, 1980-3.

[25] WD Muynck, K Cox, ND Belie and W Verstraete. Bacterial carbonate precipitation as an alternative surface treatment for concrete. Construct. Build. Mater. 2008; 22, 875-85.

[26] WD Muynck, D Debrouwer, ND Belie and W Verstraete. Bacterial carbonate precipitation improves the durability of cementitious materials. Cement Concr. Res. 2008; 38, 1005-14.

[27] HM Jonkers. Self-healing concrete: A biological approach. In: SVD Zwaag (Ed.). Self-healing materials: An alternative approach to 20 centuries of materials science. Springer, Springer, Dordrecht, 2007, p. 195-204.

[28] SJ Park, YM Park, WY Chun, WJ Kim and SY Ghim. Calcite forming bacteria for compressive strength improvement in mortar. J. Microbiol. Biotechnol. 2010; 20, 782-8.

[29] V Achal, A Mukherjee, D Kumari and Q Zhang. Biomineralization for sustainable construction: A review of processes and applications. Earth Sci. Rev. 2015; 148, 1-17.

[30] B Krajewska. Urease-aided calcium carbonate mineralization for engineering applications: A review. J. Adv. Res. 2018; 13, 59-67.

[31] S Al-Thawadi. 2008, High strength in-situ biocementation of soil by calcite precipitating locally isolated ureolytic bacteria. Ph. D. Thesis. Murdoch University, Perth, Australia.

[32] M Nemati, EA Greene and G Voordouw. Permeability profile modification using bacterially formed calcium carbonate: Comparison with enzymic option. Process Biochem. 2005; 40, 925-33.

[33] N Hafez, A Sharaky, N Mohamed and M ElMashad. 2019, Biocementation of calcite precipitation for stabilization of sandy and calcareous soils in Egypt and Tunisia. Ph. D. Thesis. Cairo University, Giza, Egypt.

[34] H Yasuhara, D Neupane, K Hayashi and M Okamura. Experiments and predictions of physical properties of sand cemented by enzymatically induced carbonate precipitation. Soils Found. 2012; 52, 539-49.

[35] JPSF Carmona, PJV Oliveira and LJL Lemos. Biostabilization of a sandy soil using enzymatic calcium carbonate precipitation. Proc. Eng. 2016; 143, 1301-8.

[36] MS El-Mahllawy, AM Kandeel, MLA Latif and AME Nagar. The feasibility of using marble cutting waste in a sustainable building clay industry. Recycling 2018; 3, 1-13.

[37] J Chisholm. Comparison of quartz standards for X-ray diffraction analysis: HSE A9950 (Sikron F600) and NIST SRM 1878. Ann. Occup. Hyg. 2005; 49, 351-8. 